\title{
Sedimentary record of Early Permian deglaciation in southern Gondwana from the Falkland Islands
}

\author{
KATE HORAN ${ }^{1,2 *}$, PHILIP STONE ${ }^{3} \&$ SIMON J. CROWHURST $^{2}$ \\ ${ }^{1}$ Department of Earth Sciences, Science Laboratories, Durham University, \\ Elvet Hill, Durham DH1 3LE, UK \\ ${ }^{2}$ Department of Earth Sciences, University of Cambridge, Downing Street, \\ Cambridge CB2 3EQ, UK \\ ${ }^{3}$ British Geological Survey, The Lyell Centre, Research Avenue South, \\ Edinburgh EH14 4AP, UK K.
}

*Correspondence: kate.horan@cantab.net

\begin{abstract}
The deglaciation of southern Gondwana during the Early Permian was preceded by waxing and waning of the south polar ice sheet. The fluctuations in ice extent are recorded in the sedimentary record by strata separating thick deposits of glacial diamictite from post-glacial mudrock. These deposits span across all of the major Gondwana fragments, now recognized as South Africa, South America, India, Antarctica and Australia, and also occur on the Falklands and Ellsworth Mountains microplates created during break-up of the supercontinent in the Mesozoic. We present sedimentary evidence for the progression of deglaciation from the Falkland Islands microplate using a series of borehole core runs acquired during onshore mineral exploration. Glacial advance and retreat phases are inferred from the Hells Kitchen Member of the Port Sussex Formation; the rock succession that conformably overlies the main body of glacial diamictite known locally as the Fitzroy Tillite Formation. The pulsated nature of the transition to fully post-glacial conditions was accompanied by an intricate interplay of sedimentary processes, including soft sediment deformation, meltwater pulses and turbidity currents. The Falkland Islands core data lend insight into the evolving Early Permian environment and offer an unusually complete view of continental margin deglaciation preserved in the ancient sedimentary record.
\end{abstract}

In: Le Heron, D.P. et al. (eds) Glaciated Margins: The Sedimentary and Geophysical Archive. Geological Society, London, Special Publications, 475.

Published online 19 March 2018, doi.org/10.1144/SP475.1 